\title{
Persistent occurrence of ureaplasmas in the oral cavity
}

\author{
Masayoshi Totsuka, Kenichiro Shibata and Tsuguo Watanabe \\ Department of Oral Bacteriology, Nagasaki University School of Dentistry, \\ 7-1 Sakamoto-machi, Nagasaki 852, Japan
}

[Accepted for publication: October 15, 1982]

Key words: ureaplasmas / persistent occurrence / saliva

Since Shepard ${ }^{1)}$ (1954) isolated tiny colony-forming mycoplasmas (T-strain, Tstrain mycoplasma, $\mathrm{T}$-mycoplasma or ureaplasma) from the urethra of man, a number of publications have described the organisms in the urogenital tract (Taylor-Robinson et al. $\left.^{2)}, 1980\right)$. However, there have been only a few papers describing ureaplasmas in the oropharynx ${ }^{3-5)}$. Watanabe et al. ${ }^{6,7)}$ isolated the organisms from the washings of the oral cavity of a female patient suffering from serious gingivitis and also from the saliva of patients afflicted with various oral diseases. These results encouraged us to study whether ureaplasmas were a member of the oral microbial flora and whether ureaplasmas were aetiologically associated with any oral diseases. In the process of the studies, the authors came across a subject from whom ureaplasmas were isolated repeatedly during a period of 15 weeks. In this communication, the authors describe the findings obtained so far, because such a case has never been reported.

\section{Materials and Methods}

The subject was a 29-year-old, male patient seeking dental care at Nagasaki University Dental Hospital; systematically healthy, he exhibited slight symptoms of gingivitis and complete dentition.

The liquid medium utilized for isolation and growth of the ureaplasmas consisted of Difco PPLO broth $(70 \%, \mathrm{v} / \mathrm{v})$, horse serum $(20 \%, \mathrm{v} / \mathrm{v}), 25 \%$ yeast extract $(10 \%, \mathrm{v} / \mathrm{v})$, thallium acetate $(0.025 \%, \mathrm{w} / \mathrm{v})$, penicillin $\mathrm{G}(1,000 \mathrm{U} / \mathrm{ml})$, urea $(0.1 \%, \mathrm{w} / \mathrm{v})$, and phenol red $(0.002 \%, \mathrm{w} / \mathrm{v})$. The reaction was adjusted to $\mathrm{pH}$ 7.0. The solid medium was a liquid medium without phenol red and with urea, the concentration of which was reduced to $0.01 \%(\mathrm{w} / \mathrm{v})$, and Oxoid agar No. $1(1 \%, \mathrm{w} / \mathrm{v})$ was added. The $\mathrm{pH}$ was adjusted to 6.5 . When used, the medium was plated in glass petri dishes measuring $4.5 \mathrm{~cm}$ in diameter.

The mixed saliva was sampled every time the subject visited the clinic. Liquid medium in $4.5 \mathrm{ml}$ amounts, contained in screw-capped glass vials of $5.5 \mathrm{ml}$ capacity, was inoculated with $0.5 \mathrm{ml}$ of saliva samples. Then, the vials were incubated at $37^{\circ} \mathrm{C}$ aerobically. The growth of ureaplasmas decomposed the urea and caused a colour change from yellow $(\mathrm{pH} 7.0)$ to red $(\mathrm{pH} \mathrm{8.0)}$. Therefore, when there was a colour change, the cultures were diluted in serial 10 -fold steps in a liquid medium. Drops $(0.05 \mathrm{ml})$ of each dilution (1:10 to $1: 100,000)$ were inoculated on agar plates, which were incubated at $37^{\circ} \mathrm{C}$ for 3 days in an atmosphere of $80 \% \mathrm{~N}_{2}, 10 \% \mathrm{CO}_{2}$ and $10 \% \mathrm{H}_{2}$. After incubation, the agar plates were examined for ureaplasma colonies under a microscope at $100 \times$ magnification. A block of solid medium (ca. $5 \times 5$ $\mathrm{mm}$ ) carrying a single colony suspected to be one of the ureaplasmas was cut off and transferred to a liquid medium. Pure cultures were obtained after 5 times of cloning.

The isolated strains were examined for susceptibility to erythromycin $(1.0 \mu \mathrm{g} / \mathrm{ml})$ and thallium acetate $(1.0 \mathrm{mg} / \mathrm{ml})$ on solid medium ( $\mathrm{pH} 7.5$ ) and for growth in a liquid medium without horse serum.

\section{Results}

Mixed saliva was sampled on 15 different occasions during a period of 15 weeks. All 
Table 1 Some properties of strains isolated from saliva

\begin{tabular}{|c|c|c|c|c|c|c|}
\hline \multirow{3}{*}{$\begin{array}{l}\text { Days } \\
\text { after } \\
\text { the 1st } \\
\text { sampling }\end{array}$} & \multirow{3}{*}{$\begin{array}{l}\text { Isolated } \\
\text { strain } \\
\text { number }\end{array}$} & \multirow{3}{*}{$\begin{array}{c}\text { Colony } \\
\text { morphology }\end{array}$} & \multicolumn{3}{|c|}{ Susceptibility } & \multirow{3}{*}{$\begin{array}{l}\text { Growth in medium } \\
\text { without horse } \\
\text { serum }\end{array}$} \\
\hline & & & Urease & thallium acetate & to erythromycin & \\
\hline & & & & $(1.0 \mathrm{mg} / \mathrm{ml})$ & $(1.0 \mu \mathrm{g} / \mathrm{ml})$ & \\
\hline 0 & $1-4$ & Typical & + & $+(1,4)^{*}$ & $+(1,4)^{*}$ & $+(1,4)^{*}$ \\
\hline 1 & $5-7$ & Typical & + & $+(5.6)^{*}$ & $+(5,6)^{*}$ & $+(5,6)^{*}$ \\
\hline 2 & $8-10$ & Typical & + & $+(8,10)^{*}$ & $+(8,10)^{*}$ & $+(8,10)^{*}$ \\
\hline 4 & $11-20$ & Typical & + & $+(18,20)^{*}$ & $+(18,20)^{*}$ & $+(18,20)^{*}$ \\
\hline 7 & $21-22$ & Typical & + & $+(21)^{*}$ & $+(21)^{*}$ & $+(21)^{*}$ \\
\hline 10 & $23-26$ & Typical & + & $+(23,26)^{*}$ & $+(23,26)^{*}$ & $+(23,26)^{*}$ \\
\hline 11 & $27-32$ & Typical & + & $+(27,31,32)^{*}$ & $+(27,31,32)^{*}$ & $+(27,31,32)^{*}$ \\
\hline 14 & $33-40$ & Typical & + & $+(33,35,37,39,40)^{*}$ & $+(33,35,37,39,40)^{*}$ & $+(33,35,37,39,40)^{*}$ \\
\hline 15 & $41-45$ & Typical & + & $+(41)^{*}$ & $+(41)^{*}$ & $+(41)^{*}$ \\
\hline 17 & $46-51$ & Typical & + & $+(46,48,49,50,51)^{*}$ & $+(46,48,59,50,51)^{*}$ & $+(56,48,49,50,51)^{*}$ \\
\hline 24 & $52-59$ & Typical & + & $+(52,59)^{*}$ & $+(52,59)^{*}$ & $+(52,59)^{*}$ \\
\hline 33 & $60-69$ & Typical & + & $+(60)^{*}$ & $+(60)^{*}$ & $+(60)^{*}$ \\
\hline 39 & $70-79$ & Typical & + & $+(70,71)^{*}$ & $+(70,71)^{*}$ & $+(70,71)^{*}$ \\
\hline 82 & $80-89$ & Typical & + & $+(80)^{*}$ & $+(80)^{*}$ & $+(80)^{*}$ \\
\hline 104 & $90-99$ & Typical & + & $+(90)^{*}$ & $+(90)^{*}$ & $+(90)^{*}$ \\
\hline
\end{tabular}

* Numbers in parentheses denote the strain number tested.

of the samples yielded ureaplasma colonies; minute $(30-60 \mu \mathrm{m}$ in diameter), round, thin and flat with a very small nipple. Ninetynine strains were isolated. Of them, 32 strains were examined for susceptibility to erythromycin and thallium acetate and growth in a medium without horse serum. All of the tested strains failed to grow in the medium without horse serum and to revert to bacterial forms, although subcultured 5 times in a medium without thallium acetate or penicillin; but were inhibited in the presence of erythromycin $(1.0 \mu \mathrm{g} / \mathrm{ml})$ and thallium acetate $(1.0 \mathrm{mg} / \mathrm{ml})$ (Table 1$)$.

Based on the results, the isolated strains were identified as Ureaplasma urealyticum, and the organisms in the oral cavity as a member of the oral microbial flora.

\section{Discussions}

Mycoplasmas were originally isolated from animals as an aetiological agent of bovine pleuropneumonia (Nocard et al. ${ }^{8)}$, 1898), and about 40 years later from humans for the first time by Dienes et al.9) (1937), who recovered the organisms from an abscessed Bartholin's gland. Since then, efforts exerted for isolation of the organisms from the oral cavity by many investigators had been in vain until Morton ${ }^{10)}$ (1951) isolated the organisms from saliva for the first time. Nevertheless, Morton's report has been followed successively by numerous publications concerning oral mycoplasmas. At the moment, knowledge regarding ureaplasmas in the oral cavity is limited and the rate of isolation frequency reported so far is very low. However, the findings presented here seem to suggest that ureaplasmas are a common inhabitant of the oral cavity. Through improvement of cultural conditions and techniques for isolation of the organisms from the specimens containing a variety of bacteria in great number, it may be demonstrated that the organisms are distributed widely in the oral cavity.

\section{References}

1) Shepard, M. C.: The recovery of pleuropneumonia-like organisms from Negro men with and without nongonococcal urethritis. 
Am. J. Syph. Gon. Vent. Dis., 38: 113-124, 1954.

2) Taylor-Robinson, D. and McCormack, W. C.: The genital mycoplasmas. N. Engl. J. Med., 302: 1003-1010 \& 1063-1067, 1980.

3) Taylor-Robinson, D. and Purcell, R. H.: Mycoplasmas of the human urogenital tract and oropharynx and their possible role in disease: A review with some recent observations. Proc. Roy. Soc. Med., 59: 1-4, 1966.

4) Ford, D. K.: Relationships between mycoplasma and aetiology of nongonococcal urethritis and Reiter's syndrome. Ann. N. Y. Acad. Sci., 143, 501-504, 1967.

5) Purcell, R. H., Wong, D. and Chanock, R. M.: Significance of antibody to mycoplasma as measured by metabolic-inhibition techniques. Ann. N. Y. Acad. Sci., 143, 664-675, 1967.
6) Watanabe, T., Takamori, K., Horikawa, T., Noguchi, T., Ishizu, T. and Kinoshita, S.: The occurrence of T-mycoplasma in oral cavities. Kokubyo Z., 38: 324-332, 1971.

7) Watanabe, T., Matsuura, M. and Seto, K.: Isolation and serological typing of ureaplasmas in human saliva. Arch. oral Biol., in press.

8) Nocard, E. and Roux, E.: Le microbe de la péripneumoniae. Ann. Inst. Pasteur (Paris), 12: 240-262, 1898.

9) Dienes, L. and Edsall, J.: Observations on the L-organism of Klieneberger. Proc. Soc. Biol. \& Med., 36: 740-744, 1937.

10) Morton, H. E., Smith, P. F., Williams, N. B. and Eickenberg, C. F.: Isolation of pleuropneumonia-like organisms from human saliva: A newly detected member of the oral flora. J. Dent. Res., 30: 415-422, 1951. 